\title{
Entrepreneurial intentions: Demographic perspectives of South African business students
}

\author{
S.M. Farrington * \\ Department of Business Management, Nelson Mandela Metropolitan University \\ PO Box 77000, Port Elizabeth 6031, Republic of South Africa \\ shelley farrington@nmmu.ac.za \\ D.J.L. Venter \\ Unit for Statistical Consultation, Nelson Mandela Metropolitan University, \\ PO Box 77000, Port Elizabeth 6031, Republic of South Africa \\ danie.venter@nmmu.ac.za \\ M.J. Louw \\ Department of Management, Rhodes University, \\ PO Box 94, Grahamstown 6140, Republic of South Africa \\ m.louw@ru.ac.za
}

\section{Received March 2012}

Entrepreneurial intentions shown by different individuals vary depending on their demographic profile. In an attempt to understand the underlying factors contributing to the low levels of entrepreneurial activity in South Africa, this study focuses on whether individuals possessing certain demographic attributes are more likely to display entrepreneurial intentions than those who do not.

The sample consisted of undergraduate business students from three South African Universities. Respondents were identified by means of convenience sampling. The statistical analysis was undertaken on 447 usable questionnaires. Chi-Square statistics were calculated to determine the significant relationships between the demographic variables and entrepreneurial intentions.

The empirical results of this study show that the demographic variables University attended, Level of study and Ethnicity have a significant influence on the intentions of respondents to start their own businesses.

*To whom all correspondence should be addressed.

\section{Introduction and problem statement}

According to Herrington, Kew and Kew (2010: 59), the total early-stage entrepreneurial activity (TEA) rate of South Africa $(5,9 \%)$ is significantly lower than the average for all efficiency-driven economies $(11,2 \%)$ as well as the average for all middle- to low-income countries (14,8\%). In 2009 South Africa ranked $35^{\text {th }}$ out of 54 countries participating in the Global Entrepreneurship Monitor (GEM) survey and reported a TEA rate of well below the average rate $(11,7 \%)$ (Herrington et al., 2010: 59). Furthermore, only $11 \%$ of South African respondents reported having entrepreneurial intentions. The other countries participating in the survey reported that on average $19 \%$ of respondents displayed entrepreneurial intentions (Herrington et al., 2010: 61). Of particular concern are the low numbers of South Africans with specific demographic profiles that are engaging in entrepreneurial activities. For example, Herrington et al.
(2010: 68) report that in South Africa men are 1,5 times more likely than women to be involved in early-stage entrepreneurial activity. Similarly, White and Indian/Asian individuals are more likely to start new business ventures than are Coloureds or Black Africans (Herrington et al., 2010: 71).

Factors influencing a person's decision to become an entrepreneur are generally categorised as demographic factors on the one hand, and attitudes, values or psychological factors on the other hand (Ashley-Cotleur, King \& Solomon, 2009). Making use of demographic variables is common when researching entrepreneurial intentions. This approach attempts to use demographic information to develop a basic entrepreneurial profile so that an assessment can be made regarding an individual's personal characteristics such as birth, role models, age, education level, family background and work habits 
(Gaddam, 2008: 39). According to Ramana, Raman and Aryasri (2009: 112), investigating differences in demographic variables relating to entrepreneurs and nonentrepreneurs is a growing area of interest in the field of entrepreneurship. In addition, Ramana et al. (2009: 113) contend that little research focus exists on the influence of demographic factors on entrepreneurial success.

According to Kristiansen and Indarti (2004), several studies support the argument that demographic variables such as age, gender and individual background (education and employment experience) influence entrepreneurial intentions. Similarly, Kiggundu (2002) asserts that various demographic variables appear to distinguish between successful and less successful entrepreneurs. The aforementioned suggests that the entrepreneurial intentions shown differ between individuals depending on their demographic profile.

According to Fatoki (2010: 91), a low level of entrepreneurial intention exists among graduates in South Africa. Most graduates prefer to work for the government or for private companies. Similar findings have been reported in other countries (Ariff, Bidin, Sharif \& Ahmad, 2010: 2) where students also prefer to be employed by others rather than being self-employed. Most studies investigating the entrepreneurial intentions of graduates have taken place in developed countries, and studies are also needed in developing countries where different conclusions could result (Barbosa \& Moraes, 2007). Opportunities for research explaining student behaviour towards entrepreneurship thus exist (Ariff et al., 2010: 2). According to Drost (2010: 28), understanding what drives entrepreneurship remains one of the most important questions being asked in management research.

It is while they are still students that potential entrepreneurs should be developed (Chen \& Lai, 2010) and educators are at a disadvantage if they fail to understand the factors that stimulate or retard entrepreneurial activity (Tajeddini \& Mueller, 2009). In order to design effective programmes, the factors that influence students' career decisions towards self-employment should be known; a better understanding of these factors is useful both from an academic and a practical point of view (Lüthje \& Franke, 2003: 136).

Against this background it is of importance and interest to entrepreneurial educators in South Africa to determine which demographic factors are associated with entrepreneurial intentions, and whether these intentions are more evident among students with specific demographic profiles. The primary objective of this study is thus to investigate the influence of selected demographic factors (i.e. Gender, Ethnicity, Level of study, University attended and Self-employment status of parents) on the entrepreneurial intentions of undergraduate business students in South Africa. More specifically the objective is to establish whether significant relationships exist between selected demographic variables and the entrepreneurial intentions of undergraduate business students at the participating universities.
By identifying which demographic groups are more or less likely to display entrepreneurial intentions, groups with shortcomings can be identified and targeted for both didactical and policy interventions. According to Urban (2010), educators must recognise that a "one-size-fits-all" approach to the training and development of future entrepreneurs may not be appropriate, and programming should be tailored and sensitised for specific groups. In general, educators of future entrepreneurs could gain from better understanding the role of demographic variables on entrepreneurial behaviour.

"Entrepreneurial intention" is a person's intention to engage in entrepreneurship (Drost, 2010: 28). According to Fatoki (2010: 88), entrepreneurial intention is one's judgement about the likelihood of owning one's own business, whereas Krueger (1993) defines entrepreneurial intention as a commitment to start a new business. As in the case of other studies (Drost, 2010; Kakkonen, 2010), "entrepreneurial intentions" in this study refers to the intentions of students to start and manage their own business in the future. The demographic variables of interest in this study are Gender, Ethnicity, Level of study (age), University attended (geographic location) and Self-employment status of parents (role models).

\section{Literature overview}

Gender differences in entrepreneurial activity are well documented in the literature (Reynolds, Bygrave \& Autio, 2004), and numerous studies (Veciana, Aponte \& Urbano, 2005; Zhao, Seibert \& Hills, 2005; Matthews \& Moser, 1995) have reported that males have a higher preference for entrepreneurial behaviour than females. For example, Urbano (2006) reported that gender significantly influences intention to start up an own business, whereas Veciana et al. (2005: 180) found a relationship between students' gender and perception of new venture desirability, as well as with their intention to create new firms, with males showing higher desirability and intentions to create firms. In their study comparing background, culture and nationalities, Zhang, Zyphur, Narayanan, Arvey, Chaturvedi, Avolio, Lichtenstein and Larsson (2009) found a higher prevalence of entrepreneurship among men than women with similar backgrounds, across cultures and national boundaries. Similarly, a study spanning 17 countries revealed that although entrepreneurship is a growing source of employment for women, the level of women involved in entrepreneurial activity remains below that of men (Langowitz \& Minniti, 2007: 341). In South Africa it is also reported that women tend to have lower entrepreneurial career aspirations than men (Herrington et al., 2010; Urban, 2010).

However, several studies (Ahmed, Nawaz, Ahmad, Sajukat, Usman, Rehman, \& Ahmed, 2010; Drost, 2010; Kakkonen, 2010) have reported that gender has no significant influence on intentions to start an own business. Ahmed et al. (2010) reported that gender does not predict entrepreneurial intentions, and Soetanto, Pribadi and Widyadana (2010: 24) found no evidence that gender has an influence on the decision of students to undertake entrepreneurial activity. In addition, most studies on entrepreneurs seem to suggest that 
few differences exist between male and female entrepreneurs (Mueller, 2004).

Numerous studies (Fairlie, 2004; Bates, 2000) have examined the relationship between ethnicity and selfemployment, consistently reporting that Black and Hispanic Americans exhibit lower rates of self-employment than other ethnic groups (Köllinger \& Minniti, 2006: 59). However, studies show that African Americans are more likely than either Hispanic or White Americans to engage in entrepreneurial activities (Dyck \& Neubert, 2010: 178). For example, Köllinger and Minniti (2006) report that although Blacks were almost twice as likely as Whites to start a business, Blacks were significantly less likely than Whites to own an established business that survived beyond the initial start-up. According to Herrington et al. (2010: 71), White and Indian/Asian South Africans are more likely to start new business ventures than are Coloureds or Black South Africans. Giacomin, Janssen, Pruett, Shinnar, Llopis and Toney (2010) reported that students were motivated by similar factors and perceived similar barriers to business creation, yet American, Asian and European students did not share the same entrepreneurial intentions. According to Raab, Stedham and Neuner (2005: 78), indications exist that cultural traditions, values, ideologies, norms and societal practices influence entrepreneurial intentions.

Ahmed et al. (2010: 18) found that the year of study was an important predictor of entrepreneurial intentions among students. Students in senior classes were more inclined toward entrepreneurship. He suggested that students in senior classes were more inclined towards entrepreneurship because of their increased knowledge and practical exposure to the field of entrepreneurship (Ahmed et al., 2010: 19). However, studies (Degeorge \& Fayolle, 2008) report that as students progress from one academic year to the next, their entrepreneurial intentions remain stable. The stability of entrepreneurial intentions over the long term implies that the academic year of study does not influence intentions (Degeorge \& Fayolle, 2008). For example, Kakkonen (2010) reported that the development of entrepreneurial attitudes did not differ between the different academic study groups or between the different years of study, but remained almost the same. Although tertiary education increases a student's awareness and knowledge of entrepreneurship in general, it does not support and enhance entrepreneurial intentions (Kakkonen, 2010). According to Kakkonen (2010), it appears that perceptions of entrepreneurship may even become more negative as students progress through their academic studies.

Several authors (Stam, 2007; Rocha \& Sternberg, 2005; Shane, 2003) contend that a person's geographic place of origin plays a significant role in entrepreneurial intentions. For example, Shane (2003) and Stam (2007), as well as Rocha and Sternberg (2005) found that students who study in urban areas have greater entrepreneurial intentions than those who study in rural areas. Similarly, Fuller-Love, Midmore, Thomas and Henley (2006: 292) assert that students who study in larger cities have more entrepreneurial intentions than those who study in smaller cities because they have more exposure to and contact with aspiring and established entrepreneurs than those in small cities do. Shane (2003: 145) reports that prospective entrepreneurs do not make decisions to exploit entrepreneurial opportunities in a vacuum, but instead are influenced by their surroundings.

Evidence exists supporting a positive relationship between the presence of role models in the family and the emergence of entrepreneurs (Veciana et al., 2005: 170). Ariff et al. (2010: 6) report that most of the students in their sample believed that family members play a significant role in encouraging them to get involved in entrepreneurial endeavours. Soetanto et al. (2010: 25) found strong evidence that parents become role models for their children, and that entrepreneurial parents give their children an opportunity to engage in business. According to Shane (2003), when parents are entrepreneurial, their children are also more likely to be entrepreneurial. Wang and Wong (2004) report a significant relationship between the family having business experience and the entrepreneurial interests of students. Similarly, Ahmed et al. (2010: 19) found a significant relationship between family business experience and entrepreneurial intentions, and concluded that where there is family business experience students are more inclined toward entrepreneurial activity. However, the findings of Kakkonen (2010) show that the existence of an entrepreneur in the core family or even among acquaintances, has no significant influence on the perceived entrepreneurial intention of the students.

Against this background the following hypotheses are formulated:

$\mathrm{H}_{0}$ : There is no relationship between the demographic variables under investigation (i.e. Gender, Ethnicity, Level of study, University attended and Selfemployment status of parents) and the entrepreneurial intentions of undergraduate business students.

$\mathrm{H}_{\mathrm{a}}$ : There is a relationship between the demographic variables under investigation (i.e. Gender, Ethnicity, Level of study, University attended and Selfemployment status of parents) and the entrepreneurial intentions of undergraduate business students.

\section{Research design and methodology}

\section{Sample and sampling method}

The email addresses of all undergraduate students registered for Business modules at Nelson Mandela Metropolitan University (NMMU), Rhodes University and Stellenbosch University were obtained from the student records of the respective universities. All respondents were given the opportunity to participate in the study on a voluntary basis, and the sampling technique can be described as convenience sampling.

\section{Measuring instrument and data collection}

In the measuring instrument, demographical information was requested and related to the Gender and Ethnicity of the respondent, as well as the University attended and Level of study. In addition, information relating to the Self- 
employment status of parents and Entrepreneurial intentions of respondents was solicited. Although entrepreneurial intent has been measured in different ways in different studies (Autio, Keeley, Klofsten, Parker \& Hay, 2001), the approach of Krueger (1993) and Veciana et al. (2005) was adopted in this study. Entrepreneurial intentions was measured by a single item, namely "Do you intend to start and manage your own business in the future?". Reponses were categorised as "Yes" or "No".

An email inviting respondents to participate in this study was sent to all undergraduate students currently studying Business-related modules at NMMU, Rhodes University and Stellenbosch University. Follow-up emails were sent reminding potential respondents of the survey after a twoweek period had passed, and once again after a four-week period had passed. The email clearly described the purpose of the study, as well as the procedure and criteria for participation. Confidentiality of responses was assured. Participation was facilitated by allowing respondents to complete the survey online. A web link was provided on the email sent to respondents.

\section{Data analysis and empirical results}

\section{Describing the sample}

In total 447 undergraduate students undertaking Businessrelated modules at their respective universities completed the questionnaire. The participating universities were NMMU, Rhodes University and Stellenbosch University, with 200, 130 and 117 respondents respectively. Almost all the respondents $(97 \%)$ were under the age of 25 . Half $(50 \%)$ of the respondents were in their first year of study, with the remaining being in the second or third year. There were slightly more females $(55 \%)$ than males $(45 \%)$ participating in the study, and the majority were people of colour (60\%). Most $(58 \%)$ respondents indicated that one or both of their parents were self-employed, whereas only $6 \%$ indicated that they themselves currently owned their own business. The majority $(68 \%)$ of respondents indicated that they intended to start and manage their own business in the future. Of those intending to start and manage their own business in the future, $62 \%$ indicated they would do so within 10 years from the present, and $100 \%$ within 20 years.

\section{Empirical results}

Chi-Square statistics were calculated to determine the significant relationships between the demographic variables and the intentions to start and manage an own business. Cramér's V statistics were calculated to establish practical significance.

A significant relationship is reported (see Table 1) for the demographic variable University attended and

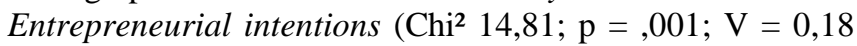
Small). Students from NMMU $(73,8 \%)$ and Rhodes $(71,1 \%)$ are significantly more likely to start and manage their own business than students from Stellenbosch $(53,4 \%)$.

The results of this study demonstrate (see Table 2) significant differences between the Levels of study and the intentions to start and manage one's own business $\left(\mathrm{Chi}^{2}\right.$ 6,$26 ; \mathrm{p}=, 044 ; \mathrm{V}=0,12$ Small). Students at more senior levels of study $\left(3^{\text {rd }} ; 2^{\text {nd }}\right)$ are more likely to have Entrepreneurial intentions than those in their first year. The majority $(76,8 \%)$ of third year and second year $(70,1 \%)$ respondents indicate that they intend to start and manage their own business, whereas only $62,4 \%$ of first year respondents report entrepreneurial intentions.

Table 1: University attended and entrepreneurial intentions

\begin{tabular}{|c|c|c|c|c|c|c|}
\hline \multirow[b]{3}{*}{ NMMU } & \multicolumn{4}{|c|}{ Entrepreneurial intentions } & \multirow{2}{*}{\multicolumn{2}{|c|}{ Total }} \\
\hline & \multicolumn{2}{|c|}{ Yes } & \multicolumn{2}{|c|}{ No } & & \\
\hline & 144 & $73,8 \%$ & 51 & $26,2 \%$ & 195 & $100,0 \%$ \\
\hline Rhodes & 91 & $71,1 \%$ & 37 & $28,9 \%$ & 128 & $100,0 \%$ \\
\hline Stellenbosch & 62 & $53,4 \%$ & 54 & $46,6 \%$ & 116 & $100,0 \%$ \\
\hline Total & 297 & $67,7 \%$ & 142 & $32,3 \%$ & 439 & $100,0 \%$ \\
\hline
\end{tabular}

$\left(\mathrm{Chi}^{2}(\mathrm{~d}\right.$ f. $=2, \mathrm{n}=439)=14,81 ; \mathrm{p}=, 001 ; \mathbf{V}=\mathbf{0 , 1 8}$ Small $)$.

Table 2: Level of study and entrepreneurial intentions

\begin{tabular}{l|r|r|r|r|r|r}
\hline \multirow{2}{*}{} & \multicolumn{3}{|c|}{ Entrepreneurial intentions } & \multicolumn{2}{c}{ No } & \multicolumn{2}{c}{ Total } \\
\cline { 2 - 7 } & \multicolumn{2}{|c|}{ Yes } & 83 & $37,6 \%$ & 221 & $100,0 \%$ \\
\hline 1st year & 138 & $62,4 \%$ & 40 & $29,9 \%$ & 134 & $100,0 \%$ \\
\hline 2nd year & 94 & $70,1 \%$ & 19 & $23,2 \%$ & 82 & $100,0 \%$ \\
\hline 3rd year & 63 & $76,8 \%$ & 142 & $32,5 \%$ & 437 & $100,0 \%$ \\
\hline Total & 295 & $67,5 \%$ & &
\end{tabular}

$\left(\mathrm{Chi}^{2}(\mathrm{~d} \mathrm{f} .=2, \mathrm{n}=437)=6,26 ; \mathrm{p}=, 044 ; \mathbf{V}=\mathbf{0 , 1 2}\right.$ Small $)$. 
No significant relationship $\left(\mathrm{Chi}^{2}=3,14 ; \mathrm{p}=, 076\right)$ is reported between the Gender of the respondents and Entrepreneurial intentions (see Table 3). This implies that whether the respondent is male or female has no influence on their intentions to start and manage their own business.

A significant relationship is reported between the Ethnicity of the respondent and their Entrepreneurial intentions $\left(\mathrm{Chi}^{2}\right.$ $=30,45 ; \mathrm{p}<, 0005 ; \mathrm{V}=0,27$ Small). The results of this study show (see Table 4) that African students are more likely $(80,0 \%)$ to start and manage their own business than their White $(56,6 \%)$ or Coloured $(46,2 \%)$ counterparts.

From Table 5 it can be seen that concerning the Entrepreneurial intentions of students participating in this study, no significant difference $\left(\mathrm{Chi}^{2}=0,0001 ; \mathrm{p}=, 992\right)$ is reported between those with entrepreneurial parents and those without. In other words the findings of this study show that the Self-employment status of parents (whether the parents own their own business or not) has no influence on the Entrepreneurial intentions of their children.

From Tables 1 to 5 it can be seen that significant relationships, albeit of small practical significance, exist between the intentions to start and manage one's own business in the future and the following demographic variables: University attended, Level of study and Ethnicity. The null-hypotheses $\left(\mathrm{H}_{0}\right)$ stating that there is no relationship between the demographic factors investigated in this study and Entrepreneurial intentions can thus be rejected for the demographic variables University attended, Level of Study and Ethnicity, but not for the variables Gender and Selfemployment status of parents.

\section{Table 3: Gender and entrepreneurial intentions}

\begin{tabular}{|c|c|c|c|c|c|c|}
\hline \multirow[b]{3}{*}{ Male } & \multicolumn{4}{|c|}{ Entrepreneurial intentions } & \multirow{2}{*}{\multicolumn{2}{|c|}{ Total }} \\
\hline & \multicolumn{2}{|c|}{ Yes } & \multicolumn{2}{|c|}{ No } & & \\
\hline & 140 & $72,2 \%$ & 54 & $27,8 \%$ & 194 & $100,0 \%$ \\
\hline Female & 154 & $64,2 \%$ & 86 & $35,8 \%$ & 240 & $100,0 \%$ \\
\hline Total & 294 & $67,7 \%$ & 140 & $32,3 \%$ & 434 & $100,0 \%$ \\
\hline
\end{tabular}

$\left(\mathrm{Chi}^{2}(\mathrm{~d} \mathrm{f} .=1, \mathrm{n}=434)=3,14 ; \mathrm{p}=, 076\right)$.

Table 4: Ethnicity and entrepreneurial intentions

\begin{tabular}{|c|c|c|c|c|c|c|}
\hline \multirow[b]{3}{*}{ White } & \multicolumn{4}{|c|}{ Entrepreneurial intentions } & \multirow{2}{*}{\multicolumn{2}{|c|}{ Total }} \\
\hline & \multicolumn{2}{|c|}{ Yes } & \multicolumn{2}{|c|}{ No } & & \\
\hline & 99 & $56,6 \%$ & 76 & $43,4 \%$ & 175 & $100,0 \%$ \\
\hline African & 172 & $80,0 \%$ & 43 & $20,0 \%$ & 215 & $100,0 \%$ \\
\hline Coloured & 12 & $46,2 \%$ & 14 & $53,8 \%$ & 26 & $100,0 \%$ \\
\hline Total & 283 & $68,0 \%$ & 133 & $32,0 \%$ & 416 & $100,0 \%$ \\
\hline
\end{tabular}

$\left(\mathrm{Chi}^{2}(\mathrm{~d} \mathrm{f} .=2, \mathrm{n}=416)=30,45 ; \mathrm{p}<, 0005 ; \mathbf{V}=\mathbf{0 , 2 7}\right.$ Small $)$.

Table 5: Self-employment status of parents and entrepreneurial intentions

\begin{tabular}{|c|c|c|c|c|c|c|}
\hline \multirow[b]{3}{*}{ Neither } & \multicolumn{4}{|c|}{ Entrepreneurial intentions } & \multirow{2}{*}{\multicolumn{2}{|c|}{ Total }} \\
\hline & \multicolumn{2}{|c|}{ Yes } & \multicolumn{2}{|c|}{ No } & & \\
\hline & 124 & $67,8 \%$ & 59 & $32,2 \%$ & 183 & $100,0 \%$ \\
\hline Either/both & 172 & $67,7 \%$ & 82 & $32,3 \%$ & 254 & $100,0 \%$ \\
\hline Total & 296 & $67,7 \%$ & 141 & $32,3 \%$ & 437 & $100,0 \%$ \\
\hline
\end{tabular}

$\left(\mathrm{Chi}^{2}(\mathrm{~d} \mathrm{f} .=1, \mathrm{n}=437)=0,0001 ; \mathrm{p}=, 992\right)$.

\section{Discussion}

The primary objective of this study was to investigate the influence of demographic factors on the entrepreneurial intentions of undergraduate business students in South Africa. The empirical results of this study show that the demographic variables University attended, Level of study and Ethnicity have a significant influence on the intentions of respondents to start and manage their own business.

The results of this study show that undergraduate business students from NMMU and Rhodes University are significantly more likely to start and manage their own business than students from Stellenbosch are. In addition, the Level of study and Ethnicity of the respondents was found to have a significant influence on the Entrepreneurial intentions of students. Students in their final year of undergraduate studies and Black students showed more entrepreneurial intentions than other groups.

Several explanations for these finding are put forward. The majority $(76 \%)$ of respondents from Stellenbosch University were in their first year of study. The number of first-year student respondents at NMMU (41\%) and Rhodes University $(42 \%)$ were significantly less $(\mathrm{p}<0,000)$. Furthermore, that vast majority $(91 \%)$ of students from 
Stellenbosch University who participated in this study were White. The influence of University attended on entrepreneurial intentions may be explained by the large number of first year and White students in the Stellenbosch University sample relative to the other participating universities, rather than the university as such. Furthermore, Stellenbosch University is well known for traditional academic studies such as engineering, medicine, law and education, where students graduating from these disciplines are more likely to enter a career as an employee after graduation than to become self-employed.

With regard to the Level of study of respondents, this finding concurs with that of Ahmed et al. (2010) who also reported that students in senior classes were more inclined to display entrepreneurial intentions than students in junior classes, but contradicted several studies (Drost, 2010; Kristiansen \& Indarti (2004); Soetanto et al., 2010) which found no relationship between age and entrepreneurial intentions. Students in their final year of undergraduate studies are more likely to be facing an immediate future career choice than students in their first or second year of study. Given the low levels of employment in South Africa it is not surprising that many senior students consider self-employment as one of their future career options, or maybe even their only option.

Contrary to the 2009 GEM survey (Herrington et al., 2010), the findings of this study concerning Ethnicity and Entrepreneurial intentions show that Black African students are more likely to display entrepreneurial intentions than White students. These findings concur with the findings of Dyck and Neubert (2010) as well as Köllinger and Minniti (2006). Although the aforementioned studies report that Black Americans are more likely than other ethnic groups to engage in entrepreneurial activities, they also report that Blacks are significantly less likely than Whites to succeed in their entrepreneurial endeavours. Köllinger and Minniti (2006: 73) contend that individual perceptions of entrepreneurship vary between Blacks and Whites, and it is these perceptions that partially explain the difference in entrepreneurial intentions between these two ethnic groups. Black Americans display high levels of confidence and optimism towards entrepreneurship, suggesting that their subjective perceptions are biased towards over-optimism relative to the perceptions of Whites (Köllinger \& Minniti, 2006: 75).

Kiggundu (2002), and Gurol and Atsan (2006) suggest that race and ethnicity may be representative of other factors more likely to influence entrepreneurial success, whereas Köllinger and Minniti, (2006: 61) conclude that constraints and not preferences are behind racial differences in business ownership. However, Herrington et al. (2010: 72) suggest that employment equity may be responsible for the low levels of entrepreneurial activity among Black South Africans. The increased demand for qualified Black Africans and the premium salaries offered make selfemployment less attractive to these individuals.

Although numerous studies (Zhang et al., 2009; Urbano, 2006; Veciana et al., 2005) indicate that males are more likely than females to show entrepreneurial intentions, no significant relationship is reported between gender and entrepreneurial intentions in this study. This finding concurs with those of Drost (2010), Kakkonen (2010), Ahmed et al. (2010) and Soetanto, et al. (2010). According to Wilson, Kickul and Marlino (2007: 398), a lack of self-confidence in their business skills and abilities could explain why fewer women engage in entrepreneurial activities than men, and Kakkonen (2010) reports that the barriers to entrepreneurship are lower for male students than for female students. However, both male and female students participating in this study were undergraduate students of business. This similar educational experience concerning entrepreneurship could contribute to similar levels of confidence and interest in entrepreneurship between the two gender groups, providing a possible explanation for the findings of this study.

One finding of this study shows that the Self-employment status of parents has no influence on the Entrepreneurial intentions of their children. This finding contradicts the literature which suggests a relationship between parents being entrepreneurial and their children showing entrepreneurial intentions (Shane, 2003), as well as between family experience with business and the entrepreneurial interest of students (Wang \& Wong, 2004). As in the case of this study, Kakkonen (2010) also reported that even an entrepreneur in the nuclear family had no significant influence on the perceived entrepreneurial intentions of the students. Kolvereid (1996) concludes that family background does not influence entrepreneurial intentions directly, but does so indirectly through its influence on attitude, subjective norms and perceived behavioural control. Whether Kolvereid (1996) provides an explanation for the results of this study warrants further investigation.

This study has investigated the influence of demographic variables on the entrepreneurial intentions of undergraduate business students at three South African Universities. Despite differences being identified between the various demographic groupings investigated in this study, research shows that it is possible to develop entrepreneurial intentions through educational programmes (Gurol \& Atsan, 2006). According to Gerry, Marques and Nogueira (2008) more young people could become successful entrepreneurs if they were identified and cultivated during their entire educational process. Therefore, the challenge facing educational institutions in South Africa is to foster an environment that stimulates entrepreneurial intentions among students of all demographic profiles.

\section{Limitations and future research}

The use of convenience sampling introduces a source of potential bias into the study and its findings can thus not be generalised to the entire South African student population. Studies show that individuals with a university degree have a higher inclination to start their own business than those that do not (Haase \& Lautenschläger, 2011; Herrington et al., 2010) and students have a more favourable attitude towards entrepreneurship than the general population (Piipponen, 2006). More specifically, students of business are more likely to display entrepreneurial intentions (Gird \& Bagraim, 2008; Raab et al., 2005) because they possibly 
will have developed these intentions during their business studies. A degree of bias is thus evident in the findings of this study. However, by focusing this study on undergraduate business students only it was not necessary to control for factors such as age, experience, income levels and education. Furthermore, this study was limited to undergraduate business students at NMMU, Rhodes and Stellenbosch Universities only, so generalising the findings to all South African students would not be appropriate. Future studies should include students from as many South African universities as is practically possible.

Entrepreneurial intentions were measured using a "Yes" or "No" response. Future studies should measure entrepreneurial intentions using several items linked to an interval scale so that more sophisticated statistical analyses such as regression analyses can be undertaken.

According to the intentions models, the intention to perform a specific behaviour is the best predictor of that behaviour (Ajzen, 1991). With this underlying assumption, this study has sought to gain a better understanding of how selected demographic factors influence entrepreneurial intentions. The entrepreneurial intentions of students were, however, queried some years before their career choices would have been made. Whether students would follow through on their intentions and actually start an own business in the future could only be established were they to be monitored into the future.

The focus of this study was on assessing the influence of selected demographic factors on the entrepreneurial intentions of undergraduate business students only. Business students are exposed to entrepreneurship during their studies. Whether this exposure has influenced the entrepreneurial intentions as perceived by the respondents in this study is, however, unknown. In future studies entrepreneurial intentions should be investigated among both business and non-business students. In this way the two groups can be compared to one another. Furthermore, this study focused on assessing the influence of selected demographic factors only. Although no past research has shown that education or income significantly influence entrepreneurial propensity (Ndubisi, 2008: 115), whether these variables influence entrepreneurial intentions in the South African context is worth further investigation.

According to Haase and Lautenschläger (2011: 2), an individual intention to undertake a specific behaviour is influenced not only by personal factors but also by situational and environmental factors. During the time of this survey, an economic crisis was being experienced world-wide. The media and personal experience relating to the number of business foreclosures could also have influenced the entrepreneurial intentions of students. Environmental factors such as a recession or an economic crisis, changes to the company law and increased taxes, could influence an individual's future career intentions, specifically the intentions to start and manage an own business. Investigating the influence of these factors could shed more light on the reasons an individual would follow an entrepreneurial career path or not.
Future studies should also attempt to identify the underlying factors inhibiting entrepreneurial success among Black South Africans as well as the factors that inhibit Black South Africans from following through on their intentions. Tajeddini and Mueller (2009) suggest that to explain the differences between entrepreneurs, social and cultural contexts should also be taken into account. Future studies relating social and cultural contexts to entrepreneurial intentions could shed some light in this regard. Furthermore, role models, both parents and other, are frequently suggested as a means of encouraging entrepreneurship among young people, but the results of this study suggest otherwise. Additional research on the importance and use of role models warrants attention.

Kiggundu (2002: 240) asserts that the ability of demographic variables to predict behaviour, as has been attempted in this study, tends to be unstable over time, especially when studied in isolation. Gaddam (2008: 39) argues that entrepreneurial attitude and entrepreneurial behaviour are theoretically better approaches to study entrepreneurial intentions than approaches using personality, environment and demographic factors, because they are behaviour-specific rather than characteristic-specific.

Despite the aforementioned limitations, this study provides insights into the demographic profile of South African business students intending to start and manage their own business in the future. Through the findings of this study a contribution to the field of entrepreneurship and entrepreneurship education has been made.

\section{References}

Ahmed, I., Nawaz, M.M., Ahmad, Z., Sajukat, M.Z., Usman, A., Rehman, W. \& Ahmed, N. 2010. 'Determinants of student's entrepreneurial career intentions: Evidence from business graduates', European Journal of Social Sciences, 15(2): 14-22.

Ajzen, I. 1991. 'The theory of planned behavior', Organizational Behavior and Human Decision Processes, 50: $179-211$.

Ariff, A.H.M., Bidin, Z., Sharif, Z. \& Ahmad, A. 2010. 'Predicting entrepreneurship intention among Malay university accounting students in Malaysia', UNITAR EJournal, 6(1): 1-10.

Ashley-Cotleur, C., King, S. \& Solomon, G. 2009. 'Parental and gender influences on entrepreneurial intentions, motivations and attitudes'. In Fatoki, O.O. 2010. Graduate entrepreneurial intention in South Africa: Motivations and obstacles, International Journal of Business and Management, 5(9): 87-98.

Autio, E., Keeley, R.H., Klofsten, M., Parker, G.J.C. \& Hay, M. 2001. 'Entrepreneurial intent among students in Scandinavia and in the USA', Enterprise and Innovation Management Studies, 2(2): 145-160.

Barbosa, E.G. \& Moraes, C.C. 2007. 'Determinants of firm's capital structure: The case of very small enterprises'. 
In Fatoki, O.O. 2010. 'Graduate entrepreneurial intention in South Africa: Motivations and obstacles', International Journal of Business and Management, 5(9): 87-98.

Bates, T. 2000. 'Financing the development of urban minority communities: Lessons of history’. In Köllinger, P. \& Minniti, M. 2006. Not for lack of trying: American entrepreneurship in black and white, Small Business Economics, 27: 59-79.

Chen, Y. \& Lai, M. 2010. 'Factors influencing the entrepreneurial attitude of Taiwanese tertiary-level business students', Social behaviour and personality, 38(1): 1-12.

Degeorge, J.M. \& Fayolle, A. 2008. 'Is entrepreneurial intention stable through time? First insights from a sample of French students', International Journal of Entrepreneurship and Small Business, 5(1): 7-27.

Drost, E.A. 2010. 'Entrepreneurial intentions of business students in Finland: Implications for education', Advances in Management, 3(7): 28-35.

Dyck, B. \& Neubert, M. 2010. Management: Current practices and new directions. Boston: Houghton Mifflin Harcourt Publishing Company.

Fairlie, R. 2004. 'Recent trends in ethnic and racial business ownership', Small Business Economics, 23(3): 203-218.

Fatoki, O.O. 2010. 'Graduate entrepreneurial intention in South Africa: Motivations and obstacles', International Journal of Business and Management, 5(9): 87-98.

Fuller-love, N., Midmore, P., Thomas, D. \& Henley. A. 2006. 'Entrepreneurship and rural economic development: A scenario analysis approach', International Journal of Entrepreneurial Behaviour \& Research, 12(5): 289-305.

Gaddam, S. 2008. 'Identifying the relationship between behavioural motives and entrepreneurship intentions: An empirical study based on the perceptions of Business Management students', The Icfaian Journal of Management Research, VII(5): 35-55.

Gerry, C., Marques, C.S. \& Nogueira, F. 2008. 'Tracking student entrepreneurial potential: Personal attributes and the propensity to business Start-ups after graduation in a Portuguese University'. [online] URL: http://www.springerlink.com/index/5t5388803n41411w.pdf.

Giacomin, O., Janssen, F., Pruett, M., Shinnar, R.S., Llopis, F. \& Toney, B. 2011. 'Entrepreneurial intentions, motivations and barriers: Differences among American, Asian and European students', International Entrepreneurship and Management Journal, 7: 219-238.

Gird, A. \& Bagraim, J.J. 2008. 'The theory of planned behaviour as predictor of entrepreneurial intent amongst final-year university students', South African Journal of Psychology, 38(4): 711-724.
Gurol, Y.Y. \& Atsan, N. 2006. 'Entrepreneurial characteristics amongst university students. Some insights for entrepreneurship education and training in Turkey', Education and Training, 48(1): 25-38.

Haase, H. \& Lautenschläger, A. 2011. 'Career choice motivation of university students', International Journal of Business Administration, 2(1): 2-13.

Herrington, M., Kew, J. \& Kew, P. 2010. Tracking entrepreneurship in South Africa: A GEM perspective. Cape Town: UCT Centre for Innovation and Entrepreneurship.

Kakkonen. M. 2010. 'International business students' attitudes of entrepreneurship', Advances in Business-Related Research Journal, 1(1): 67-77

Kiggundu, M.N. 2002. 'Entrepreneurs and entrepreneurship in Africa: What is known and what needs to be done', Journal of Developmental Entrepreneurship, 7(3): 239-258.

Köllinger, P. \& Minniti, M. 2006. 'Not for a lack of trying: American entrepreneurship in black and white', Small Business Economics, 27: 59-79.

Kolvereid, L. 1996. 'Prediction of employment status choice intentions', Entrepreneurship Theory and Practice, 20(3): 757.

Kristiansen, S. \& Indarti, N. 2004. 'Entrepreneurial intention among Indonesian and Norwegian students', Journal of Enterprising Culture, 12(1): 55-78.

Krueger, N. F. 1993. 'The impact of prior entrepreneurial exposure on perceptions of new venture feasibility and desirability', Entrepreneurship Theory and Practice, 18(1): $5-21$.

Langowitz, N. \& Minniti, M. 2007. 'The entrepreneurial propensity of women', Entrepreneurship Theory and Practice, May: 341-364.

Lüthje, C. \& Franke, N. 2003. 'The 'making' of an entrepreneur: Testing a model of entrepreneurial intent among engineering students at MIT', Rand Management, 33(2): 135-147.

Matthews, C. H. \& Moser, S. B. 1995. 'Family background and gender: Implications for interest in small firm ownership', Entrepreneurship and Regional Development, 7: 365-377.

Mueller, S. L. 2004. 'Gender gaps in potential for entrepreneurship across countries and cultures', Journal of Developmental Entrepreneurship, 9(3): 199-216.

Ndubisi, N.O. 2008. 'Gender differences in entrepreneurial traits, perceptions and usage of information and communication technologies', Academy of Entrepreneurship Journal, 14(2): 121.

Piipponen, R. 2006. 'Helsingin Kauppakorkakoulum opsielijoiden ja sielta vuonna 2000 valmistuneiden 
mastereiden urittajyyasenteet vuonna 2004'. In Drost, E. A. 2010. 'Entrepreneurial intentions of business students in Finland: Implications for education', Advances in Management, 3(7): 28-35.

Raab, G., Stedham, Y. \& Neuner, M. 2005. 'Entrepreneurial potential: An exploratory study of business students in the U.S. and Germany', Journal of Business and Management, 11(2): $71-88$.

Ramana, C.V., Raman, K.J. \& Aryasri, A.R. 2009. 'A study of socio-demographic factors on entrepreneurial attributes and success', South Asian Journal of Management, 16 (4): 111-126.

Reynolds, P.D., Bygrave, W. \& Autio, E. 2004. GEM 2003 executive report. Babson Park, MA: Babson College.

Rocha, H. \& Sternberg, R. 2005. 'Entrepreneurship: The role of clusters. Theoretical perspectives and empirical evidence from Germany', Small Business Economics, 24(3): 267-292.

Shane, S. 2003. A general theory of entrepreneurship: The individual-opportunity nexus. Cheltenham, UK: Edward Elgar.

Soetanto, D.P., Pribadi, H. \& Widyadana. G. A. 2010. 'Determinants of entrepreneurial intentions among university students', The IUP Journal of Entrepreneurship Development, VII (1\&2): 23-37.

Stam, E. 2007. 'Why butterflies don't leave. Locational behaviour of entrepreneurial firms', Economic Geography, 83(1): $27-50$.

Tajeddini, K. \& Mueller, S.I. 2009. 'Entrepreneurial characteristics in Switzerland and the UK: A comparative study of techno-entrepreneurs', Journal of International Entrepreneurship, 7: 1-25.

Urban, B. 2010. 'A gender perspective on career preferences and entrepreneurial self-efficacy', SA Journal of Human Resource Management, 8(1): 1-8.

Urbano, D. 2006. 'New business creation in Catalonia: Support measures and attitudes toward entrepreneurship'. In Kakkonen. M. 2010. 'International business students' attitudes of entrepreneurship', Advances in Business-Related Research Journal, 1(1): 67-77

Veciana, J.M., Aponte, M. \& Urbano, D. 2005. 'University students' attitudes towards entrepreneurship: A two countries comparison', International Entrepreneurship and Management Journal, 1(2): 165-182.

Wang, C.K. \& Wong, P.K. 2004. 'Entrepreneurial interest of university students in Singapore', Technovation, 24(2): 163172.

Wilson, F., Kickul, J. \& Marlino, D. 2007. 'Gender, entrepreneurial self-efficacy and entrepreneurial career intentions: Implications for entrepreneurship education', Entrepreneurship Theory and Practice, 31 (3): 387-406.

Zhang, Z., Zyphur, M.J., Narayanan, J., Arvey, R.D., Chaturvedi, S., Avolio, B.J., Lichtenstein, P. \& Larsson, G. 2009. 'The genetic basis of entrepreneurship: Effects of gender and personality', Organizational Behavior and Human Decision Processes, 110: 93-107.

Zhao, H., Seibert, S.E. \& Hills, G.E. 2005. 'The mediating role of self-efficacy in the development of entrepreneurial intentions', Journal of Applied Psychology, 90(6): 12651272. 